\title{
Az imázs, az arculat és a kommunikáció szerepe a rendőrségnél
}

\section{KÉSZ-VARGA Mónika ${ }^{2}$ - POKRÓCOS György ${ }^{2}$}

\begin{abstract}
Írásunkban azt szeretnénk bemutatni, hogy egy szervezet múködésének mennyire fontos része az a benyomás, amelyet a kivülállók körében kialakít magáról. A rendőrség, Magyarország legnagyobb közigazgatási szervezeteként minden ember számára ismert. Azok a tulajdonságai és jellemzői mindenképpen, amelyekkel az emberek naponta találkoznak. A rendöri jelleggel ellátott szolgálati jármúvek, az egyenruha, a weboldal, a közösségi média, a mikroblog vagy akár a napi médiaszereplés is. A rendőrség arculata, imázsa és kommunikációja jól felépített, tudatos tevékenység eredménye.
\end{abstract}

Kulcsszavak: rendőri imázs, arculat, kommunikáció, egyenruha, tetoválás

\section{Az arculatok és védelmük - az államalapítástól a mai rendôrségi szabályozásig}

Egy állam vagy annak katonai szervezetének önmagáról kialakított képe leginkább a címerében, zászlajában, valamint a katonái egyenruháin, páncélzatán viselt emblémákon jelent meg. Az államalapító királyunk zászlójának bár pontos ábrázolása nem maradt fenn, a 10-11. században utólagosan rekonstruálták azt a lobogót, amely fejedelmi zászló külön kíséretet és őrséget kapott és egyben az uralkodó jelenlétét is szimbolizálta. ${ }^{3}$ A király jelenlétének ilyenformán történő megjelenése, az egyedi, mással össze nem hasonlítható nemesi lobogó már üzenet volt a népnek, hogy tudja meg mindenki, hogy személyesen az uralkodó van jelen. Így, a királyhoz köthető jelvények a királyt szimbolizáló arculati eszközökké váltak, amelyek a személyes jelenlétét kifejező külső jegyek voltak. Az uralkodó mellett fontos feladat volt annak hadseregének a megjelölése is. A korabeli hadviselés céljai a politikai hatalom megőrzése, megerősítése és a hódítások voltak. Egy ilyen háborúban kiemelt volt a jelentősége annak, hogy a katonák meg tudták különböztetni egymást az ellenség katonáitól.

KÉSZ-VARGA Mónika r. őrnagy, ügyeletvezető, ORFK Kommunikációs Szolgálat

Mónika KÉSZ-VARGA, police major, chief of duty, Hungarian National Police Headquarters, Communication Service, org/0000-0001-8493-9987, keszmonika79@gmail.com

2 POKRÓCOS György dr., LL.M. r. őrnagy, kiemelt főreferens, médiajogi szakjogász, ORFK Kommunikációs Szolgálat, PhD-hallgató, Nemzeti Közszolgálati Egyetem, Közigazgatás-tudományi Doktori Iskola

György POKRÓCOS dr., LL.M., police major, media law specialist, highlighted main refrain, Hungarian National Police Headquarters, Communication Service, PhD Student, National University of Public Service, Doctoral School of Public Administration Sciences orcid.org/0000-0002-9831-7422, dr.pokrocos@gmail.com

3 www.nemzetijelkepek.hu/tortenelmi-galeria-2.shtml (2018. 05. 15.) 
Így a hadsereg arculatának kialakítása elsősorban a sikeres hadviselést szolgáló taktikai, másrészt az elegáns katona, a fényes páncél, a címerekkel ellátott pajzs látványos, hatalmat és erôt képviselő, imázs szerepet töltött be.

A jelképek használata az államalapítás előtt is elterjedt volt, és az a mai napig fennmaradt. Egy-egy szimbólum önmagában kifejezi a mögötte lévő személyt, szervezetet, vállalkozást. A technika és a kommunikációs eszközök korábban nem ismert szintre emelték a kifejezés ezen módját.

A tudomány fejlődésével, az információs társadalom kialakulásával létrejött egy virtuális társadalom, amelyben az emberek a fizikai távolságok megtétele nélkül, az országhatárok átlépésének mellőzésével a korábbiakhoz képest rendkívüli gyorsasággal szerezhettek tudomást a világ bármely táján történt eseményről, ismerhették meg az abban részt vevő szervezeteket és ismerhették fel azokat, az azonosításukra tervezett arculati jeleik alapján. Talán említeni sem kell, hogy mennyire elterjedt volt egy időben az Egyesült Államok két legnagyobb rendőrségének a Los Angeles Police Department-nek (LAPD), vagy akár a New York Police Department-nek (NYPD) a népszerűsége hazánkban is: számtalan baseballsapka, póló, szabadidős felsőruházat hordozta az említett két rendőri szerv közismert logóját. A filmekből, híradásokból is ismert rendőrségek hírneve körbejárta a világot.

Egy szervezet jelképekkel való azonosíthatósága az idők múlásával sem változott. Rendszerváltásunkig az állami szektor, majd azt követően a közigazgatás szervei is kialakítottak maguknak olyan egyedi azonosító-jelképeket, amelyeket látva csak és kizárólag az adott szerv jut a szemlélő eszébe. A közigazgatás egyik alrendszerét kitevő rendőrségi igazgatás is kialakított magának olyan jelképet, logót, azonosítókat, egyenruhát, amely alapján másokkal össze nem téveszthető módon jelenik meg a közéletben. Ezek is részét képezik a rendőrség arculatának.

A magyar rendőrség stabil megkülönböztető jelzéssel ellátott szolgálati járműveinek arculatáról, a járműveken elhelyezhető logókról, jelzetekről is szóló ORFK utasítás ${ }^{4}$ azért rendelkezik az elemek jármúveken történő elhelyezéséről, hogy az arculati elemek bevezetésével jobban érvényesüljön a rendőri jelenlét. Az utasítás részletesen rendelkezik a szolgálati gépjármű motorháztetőn, a jármű oldalain, hátulján elhelyezett jelzetekről, azok minőségi követelményeiről. A járművek egyediesítésén túl az egyenruhás rendőri állomány viselhető ruházatát is szabályok határozzák meg. Az erről szóló BM rendelet ${ }^{5}$ kimondja, hogy a rendvédelmi feladatokat ellátó szervek hivatásos állománya, valamint a rendvédelmi oktatási intézmények tanulói és hallgatói állománya csak rendszeresített, a szolgálati feladataihoz igazodó egyenruházati terméket és felszerelési cikket viselhet. Az ilyen rendszeresített ruházat viselésének további részleteit

11/2010. (OT 7.) ORFK utasítás a Rendőrség szolgálati járműveinek és a rendőri szolgálati feladatok ellátásához használt, a rendőri szerv tulajdonában lévő, bérelt, lízingelt, valamint adományozott gépjárművek rendőri jellegének kialakításáról.

5 14/2016. (V. 10.) BM rendelet a belügyminiszter irányítása alá tartozó szervek egyenruha-ellátásra jogosult személyi állományának ruházati és öltözködési szabályzatáról, valamint a különleges foglalkoztatási állomány ruházati, fegyverzeti, kényszerítőeszköz- és világítástechnikai felszereléséről. 
egy ORFK utasítás ${ }^{6}$ szabályozza, amely a hivatkozott BM rendelet végrehajtása céljából az általános rendőrségi feladatok ellátására létrehozott szerv állománya öltözködési rendjének szabályozására. Az utasítás részletesen rendelkezik a rendszeresített egyenruháról, annak viselési időszakjairól, módjairól, valamint az utasítás mellékletében az egyedi jelzések körülírásáról is.

Míg a korabeli fejedelmi zászlókat külön fegyveres kíséret védte és őrizte, napjainkban ezek a jelzetek nemcsak magánjogilag, hanem közjogilag is védettséget élveznek. A Szabs. tv. ${ }^{7}$ 137/A. §-a úgy rendelkezik, hogy szabálysértést követ el az, aki mások előtt egyenruhát jogosulatlanul visel, úgyszintén az is, aki közterületen a rendvédelmi szervek, illetve a Magyar Honvédség rendszeresített egyenruháját, azonosításra szolgáló jelvényét, ezek megtévesztésre alkalmas utánzatát jogosulatlanul viseli, továbbá az e szervekre utaló feliratot, matricát ruháján vagy jármúvén jogosulatlanul feltünteti.

A jármúvek és a viselhető egyenruha szabályozása tehát a fentiek szerint alakul. Mi a helyzet azonban azokkal a személyekkel, rendőrökkel, akik hivatásos állományúként szolgálati jelleggel ellátott rendőrautóban, egyenruhában ülnek? Létezik-e szabályozás a hivatásos állományú rendőrök kinézetével kapcsolatban?

A rendőrség szolgálati szabályzatáról szóló $B M$ rendelet ${ }^{8}$ meghatározása ${ }^{9}$ alapján a rendőr szolgálatellátásra kipihenten, az előírásoknak megfelelő tiszta és ápolt öltözetben köteles megjelenni. A rendelkezés egyrészt a szolgálat ellátására való alkalmasságot határozza meg, másrészt elvárja a testület tagjaitól, hogy megfelelő megjelenéssel jelentkezzenek szolgálatra, ami a testületről kialakított kép formálásában is részt vesz: egy állami fegyveres rendvédelmi szerv tagja ne legyen ápolatlan vagy koszos ruházatú, legalábbis a szolgálatba lépés idején. Természetesen más a helyzet, ha egy rendőri intézkedés közben a ruházat beszennyeződik. Bizonyos intézkedések esetén elkerülhetetlen az egyenruha szolgálatba lépéskori tisztaságának megőrzése. Egy lakástǔzből való mentés korommal és füsttel, elsősegélynyújtás egy közúti közlekedési baleset helyszínén akár vérrel, kutatás olyan terepen, ahol a környezeti, természeti hatások és jelenségek nem az ember általi gyalogos közlekedésre optimalizáltak, beszennyezhetik a viselt ruházatot. Ebben az esetben nem az egyenruha tisztaságának a megtartása az elsődleges feladat, hanem az emberi élet megóvása, a szolgálati feladat ellátása. A szabályzat nem rendelkezik ugyan róla, de az ilyen jellegú intézkedéseket követően kísérletet kell tenni az egyenruha tisztaságának helyreállítására, amennyiben az nem lehetséges, akkor a ruházat váltásáról kell intézkedni.

A szolgálati szabályzat továbbá előírja, hogy ha a szolgálati feladat jellegéből más nem következik, a szolgálat egyenruhában történő ellátása során a rendőr csak olyan haj-, arcszőrzet-, köröm-, illetve mükörömviseletet hordhat, amely nem akadályozza vagy veszélyezteti a szolgálati feladatok biztonságos ellátását, nem alkalmas sérülés

\footnotetext{
2/2014. (II. 12.) ORFK utasítás az általános rendőrségi feladatok ellátására létrehozott szerv Öltözködési Szabályzatának kiadásáról.

2012. évi II. törvény a szabálysértésekről, a szabálysértési eljárásról és a szabálysértési nyilvántartási rendszerről.

30/2011. (IX. 22.) BM rendelet a rendőrség szolgálati szabályzatáról.

Szolgálati szabályzat 98 . $-98 /$ A. $§$
} 
okozására, nem sérti a rendőri hivatás tekintélyét és a rendőrség müködésébe vetett közbizalmat, valamint tükrözi az egyenruha méltóságát. Ennek a rendelkezésnek elsődleges célja a biztonság. A rendőr szolgálatba lépéskor soha nem tudja és nem is tudhatja azt, hogy az adott napi feladatok milyen váratlan eseményeket tartogatnak számára. Bármikor és bárhol előfordulhat olyan esemény, ahol a rendőr fizikai beavatkozására lesz szükség: például testi kényszert vagy bilincset kell alkalmazni. 2008-ban adták ki azt az ORFK utasítást, ${ }^{10}$ amely melléklete tartalmazza a rendőri intézkedések gyakorlati végrehajtásának alapvető taktikáit, a rendőri intézkedés gyakorlati végrehajtását befolyásoló tényezőket, szempontokat, feltételeket. Ezeket csoportosítva az utasítás szubjektív tényezőként veszi figyelembe a rendőr öltözetét, megjelenését, társadalmi attitűdjét. Pontosan ezért van szükség arra, hogy a rendőr kinézete ne csak tiszta és ápolt legyen, megfeleljen a szolgálati szabályzatban meghatározottaknak, ne okozzon sérülést, ne legyen alkalmas arra, hogy akadályozza vagy veszélyeztesse a szolgálati feladatok biztonságos ellátását.

A rendelkezés második felében már a rendőri hivatás tekintélyének megőrzése, a szervezetbe vetett közbizalom megóvása, az egyenruha méltóságának tiszteletben tartása a cél. Az egyéni megjelenés a 21. században már nem olyan sablonos, mint a múlt század közepe-vége felé, az emberek már olyan, egyre kirívóbb, feltűnőbb divatot is követnek, amelyeket 30 évvel ezelőtt el sem tudtunk volna képzelni. Igaz ez a rendőrökre is, hiszen ahogy a világ is változik, a rendőri pályára jelentkező fiatalok vagy éppen a pályán évtizedek óta dolgozó személyek világnézete is alkalmazkodik a környezetéhez. A hajviselet, az arcszőrzet a mai hétköznapokban megszokott kinézete évtizedekkel ezelőtt egy közszolgánál akár megbotránkoztató is lehetett volna. Ezek a határvonalak egyértelműen szubjektív megítélés alá esnek, azonban a rendkívül kirívó, egyenruha tekintélyét sértő, a rendőrségbe vetett bizalmat romboló üzenetértékű kinézetnek a szolgálati szabályzat alapján továbbra sincs helye.

A tetoválás kérdése sok rendőrt érintő téma. Egy hatályon kívül helyezett rendelet ${ }^{11}$ a tetoválást a pigmentációs-rendellenességekkel azonos helyen - 089-es kódszám alatt - szabályozta. A rendelet alapján a tetoválást a kórelváltozásokkal azonos módon kellett értékelni, vagyis az esztétikai szempontokat kellett figyelembe venni. Alkalmas minősítést akkor lehetett kapni, ha a tetoválást a rövid ujjú ruházat eltakarta. Ezen túl figyelembe kellett venni annak elhelyezkedését, nagyságát, témáját, jellegét. Amennyiben a tetoválás nem felelt meg a felsorolt kritériumoknak, akkor alkalmatlan minősítés megállapítása volt szükséges. Ez a rendelkezés azért is érdekes, mert egy bőrelváltozásokat vizsgáló, megállapító orvos szubjektív megítélésén múlt az, hogy egy tetovált rendőrt - ha az egyéb körülményeknek megfelelt - szakmai és közerkölcsi szempontok alapján alkalmatlannak minősít-e, vagy sem. A jelenlegi szabályozás ${ }^{12}$ a tetoválásokkal kapcsolatban ennél engedékenyebb. A 21/2000. (VIII. 23.) BM-IM-TNM együttes rendeletet hatályon kívül helyező és az alkalmasságról szóló új rendelet már nem nevesíti

\footnotetext{
18/2008. (OT 10.) ORFK utasítás a rendőri intézkedések gyakorlati végrehajtásának alapvető taktikáiról.

21/2000. (VIII. 23.) BM-IM-TNM együttes rendelet.

2 57/2009. (X. 30.) IRM-ÖM-PTNM együttes rendelet.
} 
és különösen nem hasonlítja pigmentációs-rendellenességekhez a tetoválást. Szerepel azonban a rendeletben olyan előírás, ami kifejezetten az esztétikai megjelenés feltételeire utal. Ilyen lehet például a daganat által okozott, kezelése után várható elváltozás; pajzsmirigybetegségnél a nyak jelentősen megnövekedett körfogata; a fogazat állapota; az ekcéma; a testmagasság és a testsúly testarányossága; az arckoponya mechanikus sérülését, égését, fagyását, vegyszer okozta károsodását követő, a lágyrész hiánnyal gyógyuló elváltozásai, amelyek plasztikai beavatkozással rendezhetők; a lábujjak csonkolását követő heg állapota. A tetoválásoknak a jelenleg hatályos jogszabályok alapján nincs konkrét tilalma. A Készenléti Rendőrség parancsnokának azonban van egy állásfoglalása a tetoválásokkal kapcsolatban: „A nyári egyenruházatból ki nem látszó tetoválás nem kizáró ok, ha nem önkényuralmi, tiltott jelkép a tetoválás tárgya. A nyári egyenruházatból kilátszó tetoválás esetében megengedett az összességében maximum $100 \mathrm{~cm}^{2}$-t lefedő tetoválás, amennyiben nem olyan jelkép, szimbólum, ideológiai elkötelezettségre utaló forma, amely összeegyeztethetetlen a rendőri hivatással. Az e fölötti méretú tetoválás - független annak tárgyától és a fenti kritériumoknak való megfeleléstől - nem megengedhető. Nem megengedett az arcon, nyakon lévő tetoválás.”

A rendőrség és az adott rendőr megjelenésével kapcsolatban készített összefoglalóból megállapítható, hogy a rendőrség figyel arra, hogy a róla kialakult kép milyen, ezért a járművek jelzetei, az egyenruhák részletes leírásán és viselési szabályainak meghatározásán túl a rendőr mint ember kinézetét is korlátozza. Ezek a korlátozások azonban teljesíthetők és elfogadhatók.

A jogalkotó akaratának megfelel, ha a legnagyobb közigazgatási szerv, amely egy fegyveres rendvédelmi szerv, egyfajta azonosságra törekszik, és ezt az azonosságot mutatja a külvilág felé.

\section{Az imázs, az arculat és a public relations összefüggése}

„Súlyosan téved, aki a hatalom megszerzésének eszközei közül kifelejti a kommunikációt. Söt a tényleges hatalom megszerzése a kommunikációval kezdödik, amennyiben elfogadjuk a hatalom definíciójaként a mások feletti rendelkezés elvét. [...] lenyügöző kommunikációval meg lehet szerezni a hatalmat, amit ugyanilyen módon el lehet veszíteni."

Garamvölgyi László

A mottó sorai egyértelműen alátámasztják, hogy Garamvölgyi László, az ORFK volt szóvivője, a Nemzeti Bűnmegelőzési Tanács kommunikációs igazgatója szerint mekkora jelentősége van a kommunikációnak. Eszköz, amellyel a szervezetek azért, hogy az elismertséget, jó hírnevet, elfogadottságot, megbecsültséget, vagyis reputációt szerezzenek, a közmegbecsülés elérése céljaként PR-tevékenységük során élhetnek. A public relations, röviden $\mathrm{PR}$, vagy más néven közönségkapcsolatok jelentése: irányítási funkció, amely a szervezet céljai iránt megnyilvánuló társadalmi konszenzus 
és bizalmi légkör kialakulását célozza. ${ }^{13} \mathrm{~A}$ PR fogalma egy másik megközelítés szerint kapcsolatszervezés, amely olyan tervszerủ és folyamatos múveletsorozat, tevékenységegyüttes, amelynek az a célja, hogy a vállalat és közönsége, közvéleménye, illetve szúkebb és tágabb környezete között megértést, bizalmat építsen ki. ${ }^{14}$ Mindezt úgy kell alkalmazniuk, hogy az az intézmény imázsának használjon, és ne ártson. Ez az, amit sok esetben nehéz megvalósítani, különösen egy olyan szervezet életében, mint a rendőrség, amelynek tevékenysége mindenkit érdekel, és mindenkire hat, a közélet fő témája. Így manapság rengeteg érzelmi, szubjektív elem is található sok olyan megnyilvánulásban, amely a testületról szól.

Mindezek miatt különösen nagy felelősség nehezedik a rendőrség PR tevékenységére, és benne főként a kommunikációra, azon belül is a sajtókezelésre, vagyis a médiatartalom-szolgáltatókkal való kapcsolattartásra. Hiszen a rendőrségnek amellett, hogy egységes képet kell mutatnia minden állampolgár számára, még ellen is kell szegülnie adott esetben a körülötte zajló társadalmi hullámveréseknek úgy, hogy lenyugtatja a kedélyeket, és pozitív módon befolyásolja a közvéleményt. Ezáltal kedvezőbb környezetet kell teremtenie saját munkájának, a társadalom minden területén.

A feladat tehát nem egyszerű, különösen annak tükrében, ha elfogadjuk azt az axiómát, miszerint az imázs folyamatosan változik, és a szervezetek akaratán kívül is, a különböző hatásoknak köszönhetően formálódik. Ehhez járul még hozzá az is, hogy a rendőrség egy non-profit, szigorúan centralizált és militarizált államigazgatási szerv, amely a jó imázs kialakításához elkülönített büdzsével nem rendelkezik. Ennek tükrében pedig - a különböző PR-eszközök között - igencsak felértékelődik a hatékony és sikeres kommunikáció, amit a rendőrség - szemben a profitorientált társaságokkal - nem külső megbízások alapján erre szakosodott, profi PR-cégekkel, kommunikációs vállalkozásokkal kell hogy megvalósítson, hanem saját alkalmazottaival, kommunikációs szakembereivel. Azt, hogy ez a kommunikációs rendszer milyen módon épül fel, és milyen feladatok hárulnak rá a médiatartalom-szolgáltatók részére adható tájékoztatás rendjéről szóló 10/2013. (III.14.) ORFK utasítás határozza meg.

J.E. Gruning megfogalmazásában a szervezeti kommunikáció „emberek, csoportok vagy szervezetek irányított kommunikációs magatartása, vagyis a kommunikáció menedzselése a szervezet és közvéleményi között". ${ }^{15}$ Ebben az értelmezésben a szervezeti kommunikáció egyik részterülete a public relations, amelynek sajátos feladata a szervezet egészének a megjelenítése a különböző szegmensekben, illetve a velük fenntartott kétirányú kommunikációs kapcsolat működtetése és fejlesztése, amely szorosan összefonódik a nyilvánossággal és a közvéleménnyel. Feladata a szervezeti célok képviselete, megismertetése és elfogadtatása a szervezet környezetében azonosítható és a múködésére befolyással bíró érdekgazdákkal, érintettekkel. Ezért nemcsak a szorosan vett közönségét kell vizsgálnia, hanem az általános közvéleményhez való viszonyát is.

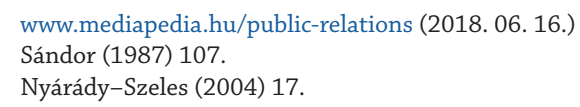


„A public relations a hírnévről szól, ami annak az eredménye, amit teszel, amit mondasz, és amit mások mondanak rólad. A public relations tevékenység az a tudományterület, amely a hírnevet gondozza azzal a céllal, hogy megértést és támogatást nyerjen és befolyásolja a véleményt és a viselkedést. A public relations munkafolyamata tervszerű és hosszan tartó erőfeszítés azért, hogy egy szervezet és a környezete között jóakaratot és kölcsönös megértést építsünk ki és tartsunk fenn." ${ }^{16}$

Ez annak függvényében igaz, hogyha a hírnévbe a közismertséget, a közvélekedést és a köztiszteletet is beleértjük. Ezek által alakul ki a szervezet imázsa, amelyet többféle tényező együttesen határoz meg. Ezek közül a három legfontosabb: a saját elvárások, a mások véleménye, valamint a személyes élmények. Tehát az imázs nem átgondolt, a tapasztalás révén szerzett empirikus vélemények összessége, hanem olyan tudati jelenséget jelöl, amelyet a legkülönbözőbb asszociációk és értékelések együttesen alkotnak. Tömören megfogalmazva: értékítéletek rendszere, vagy a kommunikációelmélet szóhasználatával élve: motivációs információhordozó. Három széles halmazból áll: szavakból, tettekből és fizikai jelenlétből.

A gazdasági, társadalmi, politikai, reálfolyamatok szempontjából megkülönböztetett imázsok közül esetünkben a szervezetimázs a legfontosabb, amelyre a testület minden intézkedése, ténykedése kihatással van. Az a rendszer pedig, amely a szervezet mindennemú imázsminősítő nyilatkozásait, minden létező aktivitását összegzi, az arculat. Ebből a felfogásból adódóan pedig az arculat objektív, vagyis az ok, míg ennek eredményeként az emberek tudatában képződő „lenyomat”, az imázs szubjektív, vagyis az okozat. ${ }^{17}$

A public relations tehát a szervezet hírnevét megformáló szakterület, és mint ilyen, a szervezeten belüli munkamegosztásban a szervezet identitásának „felelőse”. A PR az arculat megformálásával építi a szervezet imázsát oly módon, hogy totális kommunikációs megnyilvánulásaival belülről, tudatosan, stratégiailag vezérelten úgy alakítja, hogy ez a kép a szervezet gazdasági, társadalmi, szociálpolitikai helyzetének reális lehetőségein nyugvó kifejezése legyen. A szervezeti identitást szervezeti image-re fordító folyamat pedig a szervezeti kommunikáció, amiben benne foglaltatik minden, amit a szervezet tesz vagy mond. A cél nem más, mint a szervezet hírneve, vagyis az, hogy mit gondolnak, vélnek, hisznek és mondanak az adott szervezetről annak környezetében.

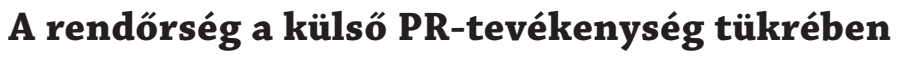

Míg a fentiekből kiderül, hogy a public relations egy viszonylag fiatal, nagyon is céltudatos, hírnévformáló szakterület, addig a rendőrség - ahol ezt számunkra alkalmazni kell - egy olyan egységes, hierarchikus fegyveres testület, amely több száz éves múltra tekint vissza, és amelyet a 19. században a jogalkotási folyamat hozott létre.

\footnotetext{
16 Az IPR (Institute of Public Relations, vagyis az Angol Public Relations Szövetség) public relations meghatározása.

17 Nyárády-Szeles (2004) 264.
} 
A rendőr szó jogszabályban első alkalommal, a mezei rendőrségről szóló 1840. évi IV. törvénycikkben látott napvilágot, míg az első rendőrségi törvény 1881-ben született meg a fővárosi rendőrségről. A rendőrködés pedig a jogalkalmazás egyik területe lett. „A modern rendőrség Európában akkor született meg, amikor a magánélet és a közélet elkülönülésével megjelent a közjog mint az állam és az egyes ember különleges viszonya. Itt már az államnak is voltak kötelezettségei a polgáraival szemben, mégpedig olyan szükségletei biztosításában, amelyeket önmaga egyedül kielégíteni nem volt képes. Az egyik ilyen első állami vállalás a közbiztonság megteremtése lett, amihez legitim erőszak monopóliumával felhatalmazott professzionális rendőrség kellett." ${ }^{18}$

Jelenleg Magyarországon a rendészeti tevékenységek kizárólagosan állami funkciók, ahol a rendészeti szervezetben csak államigazgatási hatóságok kapnak helyet. A rendőrség fő feladata nem más, mint a közbiztonság fenntartása, ami tulajdonképpen egyfajta termék, aminek a polgárok a fogyasztói. Ilyen formán pedig folyamatosan mérni kell a fogyasztói igényeket, vagyis az állampolgárok szubjektív közbiztonságérzetét, valamint a rendőrség bizalmi indexét, s javítani a termék minőségén, vagyis a közbiztonság fenntartása érdekében új intézkedéseket, stratégiákat kell bevezetni.

Miközben más megvilágításba helyeződik a rendszer, ha annak hierarchikus, katonai jellegét vesszük figyelembe. Egy fegyveres testület ugyanis egészen másképp kell hogy megszervezze kifelé folytatott kommunikációját, mint egy hétköznapi „szolgáltató" szervezet. A rendőrség tehát egyszerre civil és katonai jellegú: egyszerre államigazgatási szerv, közbiztonságot őrző testület és megelőzést folytató, szinte kreatív szervezet. Fegyveres járőrei és polgári alkalmazottai a „frontvonalon” azonnal reagáljanak, ugyanakkor a háttérben stratégiai tervezésre van szükség. Mindezt a sokfajta tevékenységi típust és területet kell hogy átfogja az állampolgárokban kialakuló egységes kép, amit úgy nevezünk, hogy „rendőrségi imázs”. A rendőrségi PR-feladat elsősorban ennek gondozása.

\section{A rendőrség imázsát alakító tényezők}

A rendőrségről minden állampolgárnak van egy benyomása, a szervezetről egy kialakult képe. Az viszont, hogy ez a kép hogyan formálódik, és milyen lesz, azt a testületről kialakított arculat határozza meg, amelyekhez számos PR-tevékenység szükséges. Hiszen az, hogy a rendőrség egy egységes, hierarchikus, fegyveres testület, még nem jelenti azt, hogy minden ember ugyanazt gondolná róla, pláne annak függvényében, hogy a rendőrségen belüli egységek, illetve megyei rendőr-főkapitányságok megítélése is más és más lehet. Azt azonban leszögezhetjük, hogy a szervezet - akár centralizáltan, akár egyes részterületei által - sajátosan tudja formálni a róla kialakult képet, akár pozitív, akár negatív irányban, és az is biztos, hogy ez mind tudatosan, általa vezérelten, mind döntésétől függetlenül, akár spontán módon végbemehet.

18 Finszter (2012) 472-473. 
Viszont tudomásul kell venni, hogy egy több száz éves szervezet gyökerét megváltoztatni nem lehet. Hiszen az emberek emlékeiben a rendőrségről ott lüktető érzéseket, gondolatokat kitörölni nem tudjuk, hiábavaló próbálkozás is lenne. Bár a teljes átváltoztatás - természetesen - nem is cél. Azonban egy-egy árnyalatnyi változtatás mégis teljesen más színben tüntetheti fel a kialakult képet.

Számos olyan külső jegy létezik, amely már alapvetően meghatározza és beazonosítja a szervezetet. A rendőrség vizuális arculata számos elemből tevődik össze. Ez határozza meg a szervezetről kialakult kép felszínét. Azt, ami az előtérben van, ami elsőként eszünkbe jut, ha azt halljuk: rendőrség. A tartalom itt még nem kap szerepet, csak a forma. Ezek közül az első a rendőrök egyenruhája, amelyet a belügyminiszter irányítása alá tartozó szervek egyenruha-ellátásra jogosult személyi állományának ruházati és öltözködési szabályzatáról, valamint a különleges foglalkoztatási állomány ruházati, fegyverzeti, kényszerítőeszköz- és világítástechnikai felszereléséről szóló 14/2016. (V.10.) BM rendelet határoz meg. Eltérés az egyes szolgálati ágak vonatkozásában lehetséges a tekintetben, hogy egyes szakterületek különböző ruházatot igényelnek, illetve ugyanide sorolható eltérés az egyes állományok tekintetében a karjelvény különbözősége is. Ezenkívül az egységes megjelenéshez hozzájárul a rendőrök külseje, fellépési módja, melyekre nézve a szolgálati szabályzat az irányadó. Jó néhány éve annak, hogy végbement a szervezeti kultúraváltás, ami a közterületen szolgálatot ellátó állomány vonatkozásában elvárásként egy mindenben segítő, támogató, a szó szoros értelmében szolgáló és védő, polgárbarát rendőrséget fogalmazott meg, amely hatékonyan és gyorsan reagál, ugyanakkor kulturáltan és udvariasan viselkedik. Ezáltal sikerült visszanyernie a rendőrségnek a tekintélyét és egyúttal a lakosság bizalmát.

A vizuális arculat velejárói még a rendőrség szolgálati igazolványa, illetve logója is, valamint a rendőrség épületei és a szolgálati gépkocsi is, amely utóbbit a rendőrség szolgálati járműveinek és a rendőri szolgálati feladatok ellátásához használt, a rendőri szerv tulajdonában lévő, bérelt, lízingelt, valamint adományozott gépjárművek rendőri jellegének kialakításáról szóló 11/2010. (OT 7.) ORFK utasítás határoz meg.

Ami az arculat tartalmát illeti, ott már a kapcsolattartásról beszélhetünk. Itt kiemelt szerepet kap az önkormányzatokkal való együttmúködés. A közbiztonság fenntartása és a bűnmegelőzés, valamint a baleset-megelőzés ugyanis közös feladatként kezelendő mind az állami szervek, mind az önkormányzatok, mind a lakosság részéről. Ebben vállal nagy szerepet a rendőrség legfontosabb stratégiai partnereként a polgárőrség is, akik önkéntesként látják el a bűnüldözési, bûnmegelőzési, valamint baleset-megelőzési tevékenységüket. A rendőrök és a polgárőrök közötti viszony is ebbe a kategóriába, vagyis az arculatformáló tényezők közé sorolandó. Ugyanúgy, ahogy a lakossággal való közvetlen kapcsolattartás, valamint a vállalkozásokkal, civil szervezetekkel és egyházakkal való együttműködés. És nem feledkezhetünk meg a külföldi szervezetekkel való kapocsról sem, amely szintén ide vehető. Utóbbira jó példa a turisztikai szezonban a horvát-magyar közös járőrszolgálat a horvát tenger- 
part idegenforgalmilag frekventált övezeteiben, amely az ott nyaraló magyarok számára egyértelműen, testközelből tapasztalható.

A leghatékonyabban és mára már legegységesebb müködő területe az imázsformálásnak azonban egyértelműen a sajtótevékenység és a médiával való kapcsolattartás.

\section{A nyilvánosság tájékoztatásának igénye}

Mivel a rendőrség mindinkább a nyilvánosság előtt végzi feladatát, a társadalom jogot formál arra, hogy betekintést nyerjen a kulisszák mögé. A közbiztonság helyzete, a bűnözés alakulása, a lakosság széles rétegeit érdeklő esetek ma már nem képezik a rendőrség belügyét. Az emberek tájékoztatásának több formája és csatornája mellett hatványozott súlya van a médiának. És a sajtómunka a rendőrségi arculatformázás egyik legfontosabb PR-tevékenységévé vált.

Köztudott, hogy a különböző médiatartalom-szolgáltatók közötti versenyből az kerül ki győztesen, aki a legújabb és a legnagyobb érdeklődésre számot tartó hírt, információt elsőként közvetíti a lakosság felé, vagyis a legtöbb olvasót, tévénézőt, rádióhallgatót gyűjti maga köré. Az emberek pedig manapság szinte éhezik a szenzációt. Enélkül a mai világban nincs üzlet, nincs profit.

A sajtóban megjelenő híradás ereje és hatása azért mutat minden más eszköz lehetőségén túl, mert a média „befogadói” előtt valóságként jelenik meg, így azt tartalmától függetlenül, igazságként kezelik.

\section{A rendőrségi sajtótevékenység}

Az élet bizonyította a rendőrség és környezete közötti kapcsolat tudatos alakításának szükségességét. Az elmúlt években tovább erősödött a kommunikációnak az igénye, amely eredményezheti, hogy a rendőrség önmagáról kedvező képet alakítson ki, és tartson fenn a társadalom szemében. Ez jelentős mértékben azon múlik, hogy miképpen alakul a rendőrség és a sajtó viszonya. Hiszen a szervezet az iránta érzett bizalmat jelentősen erősítheti a nyomtatott és az elektronikus médián keresztül. A rendőrségnél - ugyanúgy, ahogy más szervnél is - a médiával való kapcsolattartás felelőse a szóvivő.

Mivel a rendőrségi tájékoztatás mára már teljesen beágyazódott a társadalmi, közéleti kommunikációba -mostanra szinte szerves részét képezi -, a rendőrségi sajtószóvivők felelőssége megsokszorozódott. Kijelentéseiknek, megnyilvánulásaiknak, de még apróbb reakcióiknak is súlya van. A szóvivői szerepkör is azon hivatások közé tartozik, amelynek gyakorlása során az embernek minden érzelmi érintettség ellenére meg kell őriznie hidegvérét, tárgyilagosságát, cselekvőképességét. Tulajdonképpen a rendőrségi szóvivő az, aki a mindenkori cselekvők helyett beszél. Ô a rendőrség szócsöve.

A szervezet kommunikációs tevékenységének szakirányítói feladatait az Országos Rendőr-főkapitányság Kommunikációs Szolgálata végzi, az Országos Rendőr-főkapitányság Szervezeti és Működési Szabályzatában, valamint az Országos Rendőr-főkapi- 
tányság Kommunikációs Szolgálatának ügyrendjében meghatározottak alapján, összhangban a rendvédelmi feladatokat ellátó szervek hivatásos állományának szolgálati jogviszonyáról szóló 2015. évi XLII. törvénnyel és a végrehajtási rendeleteinek előírásaival, a rendőrségről szóló 1994. évi XXXIV. törvénnyel, a rendőrség szolgálati szabályzatáról szóló 30/2011. (IX.22.) BM rendelettel, valamint a médiatartalom-szolgáltatók részére adható tájékoztatás rendjéről szóló 10/2013. (III.14.) ORFK utasítással.

Az Országos Rendőr-főkapitányság Kommunikációs Szolgálata gyakorolja a szakmai iránymutatást a fővárosi, valamint a megyei rendőrségi kommunikációs szervek tevékenysége felett. Emellett a hatáskörébe tartozó ügyekben kommunikálja a rendőrség hivatalos álláspontját; szóban, illetve írásban azt közli a médiatartalom-szolgáltatókkal. Az újságírói megkereséseket kezeli és lereagálja. Az eredményes rendőri intézkedések közzététele érdekében ugyanúgy, mint az esetleges havára-események ${ }^{19}$ kommunikációjában soron kívül eljár. A rendőrség honlapján megjelenő hírek és információk legfőbb felelőse és kezelője is egyben. Ugyanúgy, mint a rendőrségi Twitteroldalnak is.

A fővárosi, illetve a megyei rendőrségi kommunikációs szervek - a fentiekre tekintettel - látják el feladataikat, a fővárosi, valamint a megyei rendőrfőkapitányok közvetlen alárendeltségében. Az egységes, komplex és központi iránymutatással múködő rendőrségi kommunikáció érdekében közvetlen a kapcsolat a szakirányító szerv és az alárendeltségébe tartozó egységek között. A rendszeres szakterületi oktatások és értekezletek adják annak lehetőségét, hogy a fő kommunikációs stratégiák, valamint az egyes kiemelt időszakok, különböző akciók és kampányok, valamint kérdéses témák és ügyek kezelése egységes módon és azonos koncepciók mellett történjen országosan.

Így mind az Országos Rendőr-főkapitányság, mind a fővárosi és a megyei rendőr-főkapitányságok kommunikációs szakembereivel szembeni alapvető elvárás, hogy a velük kapcsolatban álló sajtóorgánumokkal közvetlen kapcsolatot ápoljanak, és rajtuk keresztül minden lehetőséget megragadjanak arra, hogy a szervezet feladatainak sikeres ellátását a lakosság felé tolmácsolják, valamint a kommunikáció adta lehetőségeket kihasználva a szervezet búnüldözési, bűn- és baleset-megelőzési hatékonyságát növeljék.

A médiával való kapcsolattartás tulajdonképpen a híd a rendőrség és a sajtó között, amely munkát a rendőrségi szóvivők, referensek, valamint az ORFK sajtóügyeletesei látják el. Így felfogásukat tekintve egyszerre kell rendőrnek, újságírónak és nem utolsósorban kívülálló állampolgárnak lenniük.

A sajtóval való kapcsolattartás alapelveit meghatározza a törvényesség mint az együttmúködés kerete, az egyenrangúság és a kölcsönös előnyök, a diszkriminációmentesség, azinformációhoz történőazonoshozzáférhetőséglehetősége,valaminta személyiségi jogok védelme. A jó médiakapcsolatot kétoldalú kommunikáció jellemzi: egyfelől a szervezet a sajtóorgánumok információigényét kielégíti, másfelől a sajtó - saját szempontjai alapján - közzéteszi a híreket. Három szempont elengedhetetlen a sajtó-

\footnotetext{
19 Havária-eseménynek nevezzük az ember tevékenysége során bekövetkező váratlan, hatásában jelentős, nem szándékosan okozott eseményeket, amelyek veszélyeztetik az emberi egészséget vagy környezetet.
} 
kapcsolatok során: a kölcsönös adok-veszek viszony, a média mint szócső elfogadása, valamint a kapcsolat előkészítése. ${ }^{20}$ Jellemző rá, hogy mind a média, mind a rendőrség érdekeit szem előtt tartja úgy, hogy igyekszik kihasználni a nyilvánosságban rejlő lehetőségeket mind a szakmai munka segítése, mind pedig az elért eredmények bemutatása érdekében.

A kommunikációs tevékenység megfelelő módon történő végrehajtása, mondhatni létkérdés a rendőrség számára, alapvetően meghatározza a rendőri munka hatékonyságát. Jó kommunikációs stratégiával a lakosság rendőrségbe vetett bizalma erősödik. Ezt ismerte fel a rendőri vezetés 2013-ban, majd egy olyan új alapokon nyugvó, innovatív, komplex rendszert hozott létre, amely alkalmassá tette arra a rendőrséget, hogy tudatosan használja a média adta lehetőségeket, és a korábban heterogén kommunikációs rendszert homogénné alakítsa át, s a kommunikáció fontosságát és annak kezelését vezetői szintre emelje.

\section{A biztonság mint a rendőri munka „produktuma”}

Egy szervezet végső bírája a közönség, amelynek ítélete különböző formákban nyilvánulhat meg. Amennyiben a rendőrségről van szó, ezt az ítéletet a lakosság véleményében kereshetjük. Ennek kulcsa azonban annak tisztázása, hogy az állampolgárok mit is vár(hat)nak el a rendőrségtől. A „biztonság” fogalma az, amit gyakran értelmeznek úgy az emberek, mint egy terméket, amit a rendőrség a lakosság felé szolgáltat. Ennek kettős felfogása van: egyrészt beszélhetünk „objektív biztonságról”, amely a statisztikai adatokat és az azokból levonható következtetéseket jelenti, másrészt vehetjük a „szubjektív biztonságérzetet”, amely az adott ország állampolgárainak érzetét, véleményét, érzéseit, értékítéleteit jelenti a biztonsággal kapcsolatban. Előbbi jól mérhető, egzakt, míg utóbbi nehezen megfogható, és csak bonyolult közvélemény-kutatások által mérhető, amit az objektív biztonsági állapoton túl sok minden más is befolyásol, úgymint az adott ország gazdasági helyzete, hagyományai, politikai élete, tömegkommunikációs eszközei stb. Minden, a témával foglalkozó irodalom egyetért abban, hogy jó rendőri munkát csak úgy lehet végezni, ha a biztonság fogalmának mindkét vetületét szem előtt tartjuk.

A polgároktól érkező visszajelzések egyfajta tükröt tartanak a szervezet elé, és rámutatnak azokra a kritikus problémákra, amelyekre a leghamarabb megoldást kell találni. A kommunikáció éppen az azonnali reagálásra, korrekcióra ad lehetőséget. S olyan széles spektrumon tud mozogni, amely nagyon rövid idő alatt képes nagyon sokakhoz eljutni. Így egy nagyon tudatos médiakezeléssel az emberek biztonságérzetének igen jelentős befolyásolója lehet.

20 Nyárády-Szeles (2004) 115. 


\section{Összegzés}

A fegyveres rendvédelmi feladatokat ellátó szervezetek évezredek óta megmutatják, kifejezik magukat a külvilág felé, amely célja egyrészt a hovatartozás szimbolizálása, a másik esetlegesen ellenséges erôktől való megkülönböztetés. Másrészt pedig egyfajta üzenet is arról, hogy egy-egy ilyen szervezetnek milyen elvárásai, felszerelései, eszközei és tagjai vannak. Az ilyen benyomáskeltés a tapasztalatok bizonyos tükörképe, leképeződése ${ }^{21}$ hatással van a külvilág felé is. Bárki, aki szembetalálkozik egy ilyen kifejezéssel kialakul benne valamilyen benyomás. A jelenkori rendészeti szervek, így a rendőrség is tevékenyen részt vesz abban, hogy a róla kialakult kép minél kedvezőbb legyen. Ez egyrészt fontos a szervezet munkájának elismertetése céljából, továbbá az információs forradalom hatására rendkívüli gyorsasággal terjedő valótlan hírek helyreigazításából. A technika fejlődésével a rendőrségnek is alkalmazkodnia kellett: hírportál jellegú weboldalt üzemeltet, folyamatosan kapcsolatot tart a médiatartalom-szolgáltatókkal, tagja a közösségi médiának, és publikál mikroblogon is. Mindezt hivatalosan, a jogszabályi előírásoktól közjogi szervezetszabályozó eszközökkel történő szabályozáson keresztül végzi. Képeket, videofelvételeket készít, azokat a felhasználásra vonatkozó jogszabályi előírások figyelembevételével közzéteszi, az adott témában nyilatkozik, közleményeket ad ki, sajtótájékoztatót tart. Az ebben részt vevő személyek pedig tovább formálják a benyomást: az arculati jeleket, jelzeteket magukon viselő nyilatkozó szóvivők, sajtóreferensek vagy szakterületi képviselők megjelenésükkel is befolyásolják a rendőrségről kialakított képet. Az ilyen kommunikáció jelentősége abban merül ki, hogy ennek köszönhetően az információk szélesebb tömegekhez jutnak el. Ez pedig közérdek, hiszen a társadalomnak van olyan rétege, aki nem foglalkozik, vagy nem tud foglalkozni a biztonsági kérdésekkel, nem ismeri az aktuális veszélyhelyzeteket, megelőzési tanácsokat, közlekedési viszonyokat, a főbb baleseti okokat. Ehhez a réteghez is el kell jusson az az információ, amely egy állami szerv múködésével kapcsolatban keletkezik. $\mathrm{Az}$ így kialakult szubjektív értékítélet pedig maga az imázs. ${ }^{22} \mathrm{Az}$ imázs kialakításában pedig fontos, hogy a valótlan vagy torz értékítéleteket helyre tegyük: hiteles, gyors és pontos kommunikációval elsődleges információk közlésével és a téves vagy torz hírek korrigálásával helyreigazításával.

Ahhoz pedig, hogy az arculat, az imázs és a kommunikáció által üzent értékek eljussanak a célközönséghez, fontos az, hogy azok közérthetőek, mindenki számára felfoghatóak legyenek, ne pedig a tételes jog nyelvén vagy a jogalkalmazás nyelvén íródjanak. Alkalmazzák a technika nyújtotta lehetőségeket és folyamatosan nyomon kövessék az eseményeket. Az arculat, az imázs és a PR-tevékenység ezért fontos a mai rendőrségnek is.

\footnotetext{
21 Kotler-Keller (2006) 952.

22 Sándor (1987) 152.
} 


\section{IRODALOMJEGYZÉK}

Finszter Géza (2012): A rendôrség joga, Tanulmány a rendészeti igazgatásról. Budapest, Országos Rendőr-főkapitányság.

Nyárády Gáborné - Szeles Péter (2004): Public Relations I. Budapest, Perfekt Gazdasági Tanácsadó és Kiadó Részvénytársaság.

Kotler, Philip - Keller, Kevin Lane (2006): Marketingmenedzsment. Budapest, Akadémiai Kiadó.

Sándor Imre (1987): Marketing-kommunikáció. Budapest, Közgazdasági és Jogi Könyvkiadó.

\section{Internetes források}

Magyar nemzeti és történelmi jelképek. Forrás: www.nemzetijelkepek.hu/tortenelmi-galeria-2.shtml (2018. 05. 15.)

Médiapédia, webes média- és marketing tudástár. Forrás: www.mediapedia.hu/public-relations (2018. 06. 16.)

Institute of Public Relations. Forrás: www.instituteforpr.org/ (2018. 06. 16.)

\section{Jogszabályok, egyéb dokumentumok}

1994. évi XXXIV. törvény a Rendőrségről

2012. évi II. törvény a szabálysértésekről, a szabálysértési eljárásról és a szabálysértési nyilvántartási rendszerről

2015. évi XLII. törvény a rendvédelmi feladatokat ellátó szervek hivatásos állományának szolgálati jogviszonyáról

21/2000. (VIII. 23.) BM-IM-TNM együttes rendelet a fegyveres szervek hivatásos, közalkalmazotti és köztisztviselói állományának munkaköri egészségi, pszichikai és fizikai alkalmasságáról, a szolgálat-, illetve keresőképtelenség megállapításáról, valamint a belügyi egészségügyi szolgálat igénybevételéről

57/2009. (X. 30.) IRM-ÖM-PTNM együttes rendelet az egyes rendvédelmi szervek hivatásos állományú tagjai egészségi, pszichikai és fizikai alkalmasságáról, közalkalmazottai és köztisztviselői munkaköri egészségi alkalmasságáról, a szolgálat-, illetve keresőképtelenség megállapításáról, valamint az egészségügyi alapellátásról

30/2011. (IX. 22.) BM rendelet a rendőrség szolgálati szabályzatáról

14/2016. (V. 10.) BM rendelet a belügyminiszter irányítása alá tartozó szervek egyenruha-ellátásra jogosult személyi állományának ruházati és öltözködési szabályzatáról, valamint a különleges foglalkoztatási állomány ruházati, fegyverzeti, kényszerítőeszköz- és világítástechnikai felszereléséről

18/2008. (OT 10.) ORFK utasítás a rendőri intézkedések gyakorlati végrehajtásának alapvető taktikáiról

11/2010. (OT 7.) ORFK utasítás a Rendőrség szolgálati járműveinek és a rendőri szolgálati feladatok ellátásához használt, a rendőri szerv tulajdonában lévő, bérelt, lízingelt, valamint adományozott gépjármúvek rendőri jellegének kialakításáról

10/2013. (III. 14.) ORFK utasítás a médiatartalom-szolgáltatók részére adható tájékoztatás rendjéről

2/2014. (II. 12.) ORFK utasítás az általános rendőrségi feladatok ellátására létrehozott szerv Öltözködési Szabályzatának kiadásáról 


\section{ABSTRACT}

The Role of Image, Corporate Identity and Communication in the Police KÉSZ-VARGA Mónika - POKRÓCOS György

In our paper, we want to show what an important part it is in an organization's work the impression created by outsiders. The police, as Hungary's largest public administration organization, are known to everybody; the qualities and characteristics of the people they meet every day; police service vehicles, uniforms, websites, social media, microblogging, or even daily media outlets. The image, corporate identity and communication of the police are well-structured, conscious activities.

Keywords: police image, corporate identity, communication, uniform, tattoo 